\title{
Consumption of osmo-dehydrated Andean Berry (Vaccinium meridionale Swartz) decreases levels of pro-inflammatory biomarkers of overweight and obese adults
}

\author{
Consumo de agraz osmodeshidratado (Vaccinium \\ meridionale Swartz) disminuye los niveles de biomarcadores \\ proinflamatorios de adultos con sobrepeso y obesidad
}

Emerson Gallego-Peláez ${ }^{1 \star}$, David Torres² ${ }^{2}$ Ana Gómez² , Gladys Posada ${ }^{1}$, María Elena Maldonado-Celis ${ }^{2}$

JOURNAL VITAE

School of Pharmaceutical and Food Sciences ISSN 0121-4004 | ISSNe 2145-2660 University of Antioquia Medellin, Colombia

Filliations

${ }^{1}$ Corporación Universitaria Remington, Carrera 51 \# 49-59, Medellín, Antioquia, Colombia.

${ }^{2}$ Escuela de Nutrición y Dietética, Ciudadela de Robledo Cra. 75 \# 65-87, Universidad de Antioquia, Medellín AA 1226, Colombia

*Corresponding Emerson Gallego-Peláez emersongallego@gmail.com

Received: 30 September 2020 Accepted: 22 April 2021 Published: 18 June 2021

\begin{abstract}
Background: A Body Mass Index (BMI) greater than $24.9 \mathrm{Kg} / \mathrm{m}^{2}$ promotes chronic inflammation due to increased secretion of pro-inflammatory adipokines. Consuming fruits rich in bioactive compounds such as berries is a promising strategy to counteract this effect. Objectives: Determine the effect of osmo-dehydrated Andean Berry consumption on inflammatory biomarkers (TNF- $\alpha$, IL-6, IL-1 $\beta$, and adiponectin) and plasma antioxidant capacity in overweight and obese adults after 21 days. Methods: Andean Berry was osmo-dehydrated in $70 \%$ sucrose syrup. Antioxidant activity, proximal composition, phenolic content, microbiological analysis, and sensory analysis of the product were determined. Twenty-five obese and overweight subjects consumed $35 \mathrm{~g}$ of osmo-dehydrated berry for 21 days. Inflammatory biomarkers and antioxidant capacity in plasma were evaluated at the beginning and end of the study. Results: Osmo-dehydrated Andean Berry presented a total phenolic content of $692.7 \pm 47.4$ $\mathrm{mg}$ Gallic Acid Equivalents/100 g. All biomarkers evaluated in the subjects showed statistically significant differences ( $p>0.05$ ), except for CRP, before and after the study. IL-6 presented the more significant reduction among all pro-inflammatory adipokines with an effect size of 18.4 Conclusions: Regular consumption of osmo-dehydrated Andean Berry contributes to decreasing pro-inflammatory biomarkers and improves the plasma antioxidant capacity of overweight and obese adults.
\end{abstract}

Key words: adipose tissue; inflammation; adipokines; berry; osmotic-dehydration.

\section{Abbreviations}

IL-1 $\beta=$ Interleukin-1 $\beta$, IL-6= Interleukin- 6 , TNF- $\alpha=$ Tumor Necrosis Factor $\alpha, B M I=$ Body Mass Index, $\mathrm{CRP}=\mathrm{C}$ - reactive protein. 


\section{RESUMEN}

Antecedentes: un índice de masa corporal (IMC) superior a $24.9 \mathrm{~kg} / \mathrm{m}^{2}$ promueve la inflamación crónica debido al aumento en la secreción de adipocinas proinflamatorias. El consumo de frutas ricas en compuestos bioactivos como las bayas es una estrategia prometedora para contrarrestar este efecto. Objetivo: Determinar el efecto del consumo de agraz osmodeshidratado en biomarcadores inflamatorios (TNF- $\alpha$, IL-6, IL-1 $\beta$ y adiponectina) y capacidad antioxidante plasmática de adultos con sobrepeso y obesidad después de 21 días. Métodos: El agraz fue osmo-deshidratado en jarabe de sacarosa al 70\%. Se determinó la actividad antioxidante, composición proximal, contenido fenólico, análisis microbiológico y análisis sensorial del producto. Veinticinco sujetos obesos y con sobrepeso consumieron $35 \mathrm{~g}$ de agraz osmodeshidratado durante 21 días. Se evaluaron biomarcadores inflamatorios y capacidad antioxidante en plasma al inicio y al final del estudio. Resultados: El agraz osmodeshidratado presentó un contenido fenólico total de $692.7 \pm 47.4 \mathrm{mg}$ GAE / $100 \mathrm{~g}$. Todos los biomarcadores evaluados en los sujetos mostraron diferencias estadísticamente significativas ( $p>0.05)$, a excepción de la PCR, antes y después del estudio. La IL-6 presentó la mayor reducción entre todas las adipocinas proinflamatorias con un tamaño del efecto de 18.4 Conclusiones: El consumo regular de agraz osmodeshidratado contribuye a disminuir los biomarcadores proinflamatorios y mejora la capacidad antioxidante plasmática de adultos con sobrepeso y obesidad.

IL-1 $\beta=$ Interleucina-1 $\beta$, IL-6 = Interleucina-6, TNF- $\alpha=$ Factor de necrosis tumoral $\alpha, I M C=$ Índice de masa corporal, PCR = Proteína $C$ reactiva.

\section{INTRODUCTION}

According to the World Health Organization (WHO), overweight and obesity are the "abnormal or excessive accumulation of fat that can be harmful to health". In 2016, the worldwide prevalence of adults with overweight and obesity was $39 \%$ and $13 \%$, respectively (1). At present, high BMI levels are the main risk factor for developing non-communicable chronic diseases; this risk factor is comparable or even higher than that generated by tobacco consumption (2).

The excessive increment in adipose tissue expansion, especially in the abdominal area (visceral and subcutaneous), leads to a hypertrophy state in the adipocyte. This hypertrophy generates mitochondrial dysfunctions, damage in the endoplasmic reticulum, higher macrophage infiltration in the adipose tissue stroma, and an increase in pro-inflammatory adipokines secretion, promoting the development of low-grade chronic inflammation $(3,4)$.

More than $20 \%$ of all cancers are associated with the previous initiation of chronic inflammation (hepatocellular carcinoma, breast, colorectal and gastric cancer) (5). Chronic inflammation is preceded by a greater secretion of pro-inflammatory cytokines such as IL-1 $\beta, I L-6$, and TNF $\alpha$; and a decrease in the synthesis of anti-inflammatory adipokines as adiponectin. IL-6 and TNF $\alpha$ induce the signal transducer and activator of transcription 3 (STAT3) and nuclear factor- $\kappa \mathrm{B}$ (NF- $\kappa \mathrm{B})$ signaling in cancer cells, leading to the suppression of apoptosis and the promotion of cell cycle progression. In parallel, genomic destabilization can be promoted by cytokine-mediated ectopic expression (IL-1 $\beta$ and
TNF $\alpha$ ) of activation-induced cytidine deaminase (AID) and by hypoxia-dependent suppression of DNA repair mechanisms, facilitating cancer progression (6).

Alternatively, adiponectin is a hormone produced exclusively in adipocytes and whose secretion is inversely proportional to the body weight. It has shown an anti-inflammatory function by inhibiting IL-6-induced STAT-3 phosphorylation, activation, and antiproliferative effects by regulating cell cycle (p21/p27/p53/cyclins) signaling pathways $(7,8)$.

A promising strategy for preventing cancerassociated inflammation is chemoprevention through natural bioactive compounds presents in fruits and vegetables (9). Berries are a food of wide global consumption and are among the richest fruits in vitamins, minerals, fiber, and bioactive compounds, especially anthocyanins and phenolic acids (10). In vitro and in vivo studies have shown anti-inflammatory effects of berries of the genus Vaccinium and their bioactive compounds by decreasing pro-inflammatory cytokines and increased adiponectin (11-14).

Food with these potential protective properties is the Andean Berry (Vaccinium meridionale Swartz). This berry has a high anthocyanin and phenolic content and an antioxidant activity greater than that of other berries of the same genus (cranberry, blueberry, and bilberry) $(15,16)$. However, there is currently no evidence of its anti-inflammatory and antioxidant effects on human health supported by in vivo studies. So far, only its antioxidant, antiinflammatory, and anticancer capacity have been described from in vitro studies (17-19). 
In recent years, osmotic dehydration has received attention for the several benefits it has, such as: a) osmo-dehydration in different solutions turns out to be the best method to obtain dehydrated and minimally processed fruits and vegetables due to the high sensory similarity between the dehydrated and the natural product; b) minor loss of nutrients and bioactive compounds, compared to other methods that use high temperatures; c) it inhibits enzymatic browning; d) when using sucrose it turns out to be cheaper due to the low cost of this product in the market; and e) due to the passage of different compounds such as anthocyanins from the fruit to the osmotic solution, new food ingredients with possible functional potential could be obtained from it $(20,21)$. Thus, this study aimed to determine the effect of osmo-dehydrated Andean Berry consumption on inflammatory biomarkers (TNF- $\alpha, \mathrm{IL}-6, \mathrm{IL}-1 \beta$, and adiponectin) and plasma antioxidant capacity in overweight and obese adults after 21 days.

\section{MATERIALS AND METHODS}

\subsection{Preparation of osmotic-dehydrated fruit}

Andean Berries were obtained from El Retiro Village, located in the rural area of the Antioquia Department, Colombia, at 2,175 m.a.s.l, with an average temperature of $15^{\circ} \mathrm{C}$ and relative humidity of $64 \%$. The berries during the maturation stage six (violaceous black) were collected randomly and selected according to the CIELAB color classification system (22). The berries were washed with water, disinfected in 50 ppm sodium hypochlorite solution, and washed again with water. The osmotic dehydration was performed in $70 \%$ sucrose syrup in a 1/3 ratio (1 fruit: 3 syrup). The berries were maintained in sucrose syrup for $24 \mathrm{~h}$ on a shaker at $80 \mathrm{rpm}$ and then taken to a food dehydrator (Cabela's TS160D) for a period of $14 \mathrm{~h}$ at $60^{\circ} \mathrm{C}$. The dehydrated fruit was stored in a refrigerator at $4{ }^{\circ} \mathrm{C}$ in Ziploc ${ }^{\circledR}$ bags.

\subsection{Proximate composition}

Association of Analytical Communities (AOAC) and Colombian Technical Guidelines (CTG) were used to determine moisture (method CTG 1.14), ash (method AOAC 923.03), lipid (method CTG 6.1), nitrogen (method AOAC 954.01 Micro Kjeldahl method), and protein (nitrogen X 6.25 Micro Kjeldahl method). Carbohydrates and calorie values were obtained by calculation from the components.

\subsection{Microbiological analysis}

Molds and yeasts recounts were performed according to the Colombian Technical Norms ISO 21521-1 and ISO 21521-2, and taking into count the limits established by the Colombian Resolution $3929 / 2013$ for dehydrated fruits.

\subsection{Sensory evaluation}

Nine trained judges performed the sensory evaluation in the Sensory Analysis Laboratory of the University of Antioquia, according to the Colombian Technical Norms 3501, 3932, and Colombian Technical Guidelines 165, 180, and 226.

\section{$2.5 \alpha, \alpha$-diphenyl- $\beta$-picrylhydrazyl (DPPH) free radical scavenging assay}

The activity to scavenge the stable radical DPPH was estimated according to the method described by Brand-Williams et al. with some modifications (23). The method is based on the reaction of $10 \mathrm{~mL}$ of the sample with $990 \mathrm{~mL}$ of DPPH solution for $30 \mathrm{~min}$ at room temperature. The absorbance decrease is associated with a reduction in the DPPH concentration and measured at $517 \mathrm{~nm}$. The results were expressed in Trolox equivalent antioxidant capacity (TEAC).

\section{6 Ferric Reducing/Antioxidant Power (FRAP) assay}

The antioxidant capacity of the dehydrated berry was measured according to the procedure described by Benzie et al. (24), with certain modifications. This method is based on the absorbance increment due to the formation of 2, 4, 6-tripyridil-s-triazine (TPTZ)-Fe (II) in the presence of reducing agents. A volume of $50 \mu \mathrm{L}$ of the extract was mixed with $950 \mu \mathrm{L}$ FRAP reagent previously dissolved in an acetate buffer ( $\mathrm{pH}$ 3.6). The absorbance increase was measured at $590 \mathrm{~nm}$. The FRAP values were expressed as AEAC (ascorbic acid equivalent antioxidant capacity: $\mathrm{mg}$ ascorbic acid per L) using an ascorbic acid standard curve.

\subsection{Oxygen radical absorbance capacity (ORAC) assay}

The ORAC assay was determined using the following methodology: $3 \mathrm{~mL}$ were prepared with $21 \mu \mathrm{L}$ of $10 \mu \mathrm{M}$ fluorescein solution, $2899 \mu \mathrm{L}$ of $75 \mu \mathrm{M}$ phosphate buffer (pH 7.4), $50 \mu \mathrm{L}$ of $600 \mathrm{mM}$ 2,2'-Azobis(2-amidinopropane) dihydrochloride 
(AAPH) and $30 \mu \mathrm{L}$ of extract. Fluorescence was recorded on a Perkin Elmer LS45 spectrofluorometer with a thermostated multicell. The ORAC value $\mu \mathrm{mol}$ Trolox/L was calculated using the following equation:

$$
\text { ORAC value: } \frac{\left({ }^{\text {AUC }} \text { sample }-{ }^{A U C}\right. \text { control) }}{{ }_{\text {AUC }} \text { trolox }-{ }^{A U C} \text { control }} \mathrm{F} \text { [trolox] }
$$

Where AUC is the area under the curve for sample control (AUC ${ }^{\circ}$ ), and Trolox reference (AUCTrolox) (25).

\subsection{Total phenols}

The total phenolic content was measured according to the adapted Folin-Ciocalteu method (26). The extracts $(50 \mu \mathrm{L})$ were mixed with $125 \mu \mathrm{L}$ of FolinCiocalteu reagent and $400 \mu \mathrm{L}$ of sodium carbonate solution $(7.1 \% \mathrm{p} / \mathrm{v})$, and the resulting solution was brought to a final volume of $1,000 \mu \mathrm{L}$. The mixture was stirred and stored at room temperature for 30 min in the dark. The absorbance was measured at $760 \mathrm{~nm}$ against a control sample. Aqueous solutions of gallic acid were used to build a calibration curve. The results were expressed as gallic acid equivalents (GAE)/L.

\subsection{Study design}

A quasi-experimental study with an intervention period of 21 days ( 3 weeks) was conducted. Twentyfive overweight and obese men and women were recruited and given 21 osmo-dehydrated Andean berry packs. Throughout the study, the diet or lifestyle of the participants did not change. However, they were instructed to avoid the consumption of other berries or fruits with similar bioactive compound content. The weight and height of each subject were measured to calculate the body mass index. The subjects' diets were assessed before and after the intervention using $72 \mathrm{~h}$ recall. All subjects received the fruit packed in 21 Ziploc $^{\circledR}$ bags in portions of 35 grams for daily consumption and were asked to keep them at room temperature. Fasting venous blood samples were collected at the beginning and end of the intervention from each subject. Blood was collected in heparinized tubes and centrifuged to obtain plasma for antioxidants and inflammatory biomarker analysis.

\subsection{Subjects}

Twenty-five overweight and obese men and women (aged 25 to 50 years) from the Medellín and Envigado cities were recruited in the study. Subjects should not have any following condition: endocrine, liver, kidney, cardiovascular or gastrointestinal diseases, psychological illness, eating disorders, pregnancy, lactation, asthma and allergies, tobacco or nutritional supplements consumption, use of insulin, metformin, or victoza. The study conducted according to the guidelines established in the Declaration of Helsinki and was approved by the Human Ethics Committee of Dentistry Faculty from the University of Antioquia in their session of September 30 ${ }^{\text {th }}$, record 08, concept No24- 2016. Informed consent was obtained from all subjects, and their personal information was kept under strict privacy.

\subsection{Anthropometric Indicators}

At the beginning (day 1) and at the end of the study (day 22), weight and height were measured by two Nutritionists according to Colombian Resolution 2465/2016 and using weighing scale SECA Robusta 813 and portable stadiometer SECA 213 , respectively.

\subsection{Blood Sampling}

At the beginning (day 1) and at the end of the study (day 22), venous blood samples $(10 \mathrm{~mL}$ ) were collected from all fasting volunteers in tubes containing sodium heparin. Each blood sample was centrifuged for $15 \mathrm{~min}$ at 1,372 rcf. Plasma was carefully separated into microcentrifuge tubes and stored at $-80{ }^{\circ} \mathrm{C}$ until use. Erythrocytes were mixed with $5 \%$ metaphosphoric acid in water $(\mathrm{w} / \mathrm{v})$, stored on ice for $10 \mathrm{~min}$ and centrifuged at $16,128 \mathrm{rcf}$ for 10 minutes at $4^{\circ} \mathrm{C}$. Finally, the supernatant was collected and stored at $-80{ }^{\circ} \mathrm{C}$ until analyzed.

\subsection{Inflammatory biomarkers and plasma antioxidant capacity}

On day 1 and day 22 of the intervention, inflammatory biomarkers levels (interleukin-1 $\beta$, interleukin-6, TNF- $\alpha, C$-Reactive Protein (CRP), adiponectin), and antioxidant capacity, were determined in plasma by using the Human ELISA kits (Cayman Chemical and SPI Bio) and Antioxidant Assay Kit (Cayman Chemical) respectively, according to manufacturer's instructions.

\subsection{Statistical analysis}

Data are presented as mean \pm standard deviation (SD) for normally distributed data or median and p25- p75 for data with non-normal distribution. The normality was established by the Shapiro Wilk 
test and the goodness of fit by the Pearson Chisquare test ( $p>0.05)$., Student's t-test for repeated samples and the Wilcoxon test were used $(p<0.05)$ for statistical differences. The magnitude of the effect was evaluated by the Hedges $g$ or the effect size for the Wilcoxon $T$ procedure. A general linear model (GLM) of repetitive measurements was used to evaluate the effect size of parameters material significance through the partial square eta. Statistical analysis was performed using the software SPSS version 24 (IBM).

\section{RESULTS}

\subsection{Characteristics of the osmo-dehydrated Andean Berry}

Table 1 shows the nutritional composition of the product. After the osmo-dehydration process, the berry retained a large part of its aqueous content, corresponding to almost $60 \%$ of its total weight. Carbohydrates were the most predominant macronutrient (37.6\%), followed by protein and total fat. Table 2 shows that the method in which the product presented a greater antioxidant capacity was in the hydrophilic ORAC.

Table 1. Proximate composition and microbiological profile of osmo-dehydrated Andean Berry.

\begin{tabular}{|l|l|c|}
\hline \multicolumn{1}{|c|}{ Parameter } & \multicolumn{1}{|c|}{ Method } & Value \\
\hline Moisture $(\% \mathrm{w} / \mathrm{w})$ & CTG 1.14 & 59.93 \\
\hline Total Ash $(\% \mathrm{w} / \mathrm{w})$ & AOAC 923.03 & 0.38 \\
\hline Total Fat $(\% \mathrm{w} / \mathrm{w})$ & CTG 6.1 & 0.13 \\
\hline Total Nitrogen $(\% \mathrm{w} / \mathrm{w})$ & AOAC 954.01 Micro Kjeldahl & 0.31 \\
\hline Total Protein (Nx6.25) $\% \mathrm{w} / \mathrm{w})$ & AOAC 954.01 (coefficient 6.25) Micro Kjeldahl & 1.95 \\
\hline Total Carbohydrates $(\% \mathrm{w} / \mathrm{w})$ & Calculation from the components & 37.61 \\
\hline Total Calories (Kcal/100 g) & Calculation from the components & 159.38 \\
\hline Molds and Yeasts Recount (CFU) & ISO 21521-1 and ISO 21521-2 & $<100$ \\
\hline
\end{tabular}

CTG: Colombian Technical Guideline. CFU: colony-forming unit.

Table 2. Total phenol content and antioxidant activity of osmo-dehydrated Andean Berry.

\begin{tabular}{|l|c|}
\hline \multicolumn{1}{|c|}{ Parameter } & Value \\
\hline Total polyphenols $(\mathrm{mg} \mathrm{GAE} / 100 \mathrm{~g})$ & $692.7 \pm 47.4$ \\
\hline ORAC Hydrophilic Fraction $(\mu \mathrm{mol} \mathrm{TE} / 100 \mathrm{~g})$ & $11,490.8 \pm 631.6$ \\
\hline FRAP $(\mu \mathrm{mol} \mathrm{TE} / 100 \mathrm{~g})$ & $4,084.5 \pm 106.1$ \\
\hline DPPH $(\mu \mathrm{mol} \mathrm{TE} / 100 \mathrm{~g})$ & $5,731.6 \pm 108.8$ \\
\hline
\end{tabular}

Results are the average of 3 independent experiments \pm SD. ORAC: Oxygen Radical Absorbance Capacity. FRAP: Ferric Reducing Antioxidant Power. DPPH: $\alpha$, $\alpha$-diphenyl- $\beta$-picrylhydrazyl free radical scavenging method. mg GAE: mg gallic acid equivalent. $\mu$ mol TE: micromol Trolox Equivalent.

\subsection{Sensory analysis}

As shown in figure 1, the osmo-dehydrated berry presented intensity above 3.5 in the evaluated attributes for the descriptors of appearance. Note that homogeneity was visualized in the color of each fruit, but this could have presented variation among the units that made up the sample. The osmo-dehydrated Andean berry presented intensities above 3 for sweet and fruity smell, and intensities lower than 3.0 for floral and plum, in the descriptors of odor. In flavor descriptors, the sample presented intensities below 3.0 for all attributes except for the acid (3.7), fresh (3.7), and fruity (3.9) flavors. The berry presented intensities above 3 for all descriptors in terms of texture, except for the crunchy (1.7) and chewable (2.8) attributes. Finally, according to the qualification of the evaluating judges, the osmo-dehydrated fruit obtained a general score of 3 , which classifies it as a product of high organoleptic quality. 


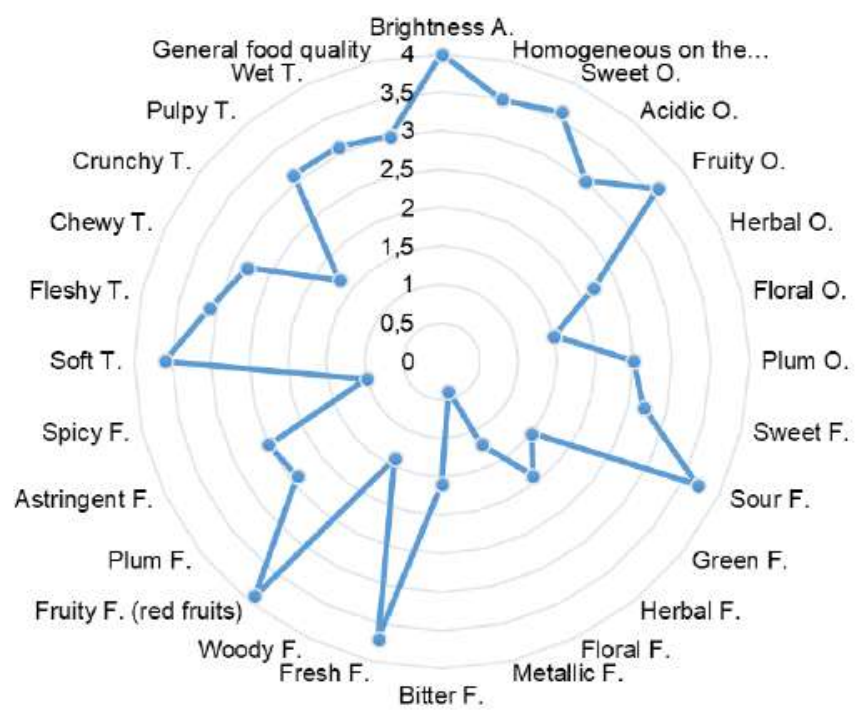

A: appearance. O: odor. F: flavor. T: texture.

Figure 1. Sensory profile by multidimensional approach osmo-dehydrated Andean Berry.

\subsection{Effect in anthropometric indicators, inflammatory biomarkers and plasma antioxidant capacity}

BMI showed a statistically significant reduction; however, its effect size was small. The levels of all pro-inflammatory biomarkers evaluated (IL-6, II-1ß, TNF- $\alpha$ ) except for CRP were significantly reduced between day 1 and day 22 of the study. The largest effect size in this decrease was that presented by IL-6. Adiponectin values and plasma antioxidant capacity of the group showed a statistically significant increase at the end of the intervention.

\section{DISCUSSION}

In this study, a ready-to-eat product was designed through the osmo-dehydration of a Colombian berry (Vaccinium meridionale Swartz) known as Andean Berry, and its antioxidant capacity and reductive effect on proinflammatory biomarkers were evidenced.

The osmotic dehydration process generated a reduction of $37.5 \%$ of the initial berry weight; however, the osmo-dehydrated product presented a significant water content equivalent to $60 \%$ of its total weight. The difference in the total carbohydrate content between the osmo-dehydrated fruit (37.6 $\mathrm{g} / 100 \mathrm{~g})$ and its fresh pulp (14.9 g / $100 \mathrm{~g}$ ) was $22.7 \mathrm{~g}(15)$, indicating that the osmo-dehydration process generated a gain of sugars from the sucrose syrup. These represent $60.3 \%$ of the total carbohydrates present in the osmo-dehydrated berry. Carbohydrates provided $94.4 \%$ of the product caloric value, while proteins provided $4.8 \%$ and fats $0.8 \%$. The $35 \mathrm{~g}$ serving consumed by the participants of this study presented a total caloric value of 55.7 $\mathrm{Kcal}$ and $31.6 \mathrm{Kcal}$ from simple sugars; these values correspond to only $2.8 \%$ and $1.5 \%$, respectively, of a 2000 calorie diet. Therefore, the contribution of simple carbohydrates in the $35 \mathrm{~g}$ portion of the osmo-dehydrated berry is within the recommended ranges according to the Colombian Clinical Practice Guide for the diagnosis, treatment, and follow-up of type 2 diabetes mellitus in the population over 18 years old (10\% of total kcal/day) (27). Thus, these results suggest that regular consumption of this

Table 3. Effect of osmo-dehydrated Andean Berry consumption on anthropometrics, inflammatory biomarkers and plasma antioxidant capacity.

\begin{tabular}{|c|c|c|c|c|c|}
\hline Parameter & Initial Time (Day 1) & Final Time (Day 22) & $p$ value & Effect Size ( $95 \%$ C.I.) & GLM Partial Eta Squared \\
\hline $\mathrm{IL}-1 \beta(\mathrm{pg})$ & $21.1(1.6)^{\star}$ & $20.4(1.4)^{\star}$ & $0.000^{\star \star}$ & $0.87(0.58 \text { to } 1.18)^{r}$ & 0.67 \\
\hline IL-6 (pg) & $19.7(2.6)^{\star}$ & $1.4(0.3)^{\star}$ & $0.000^{\star \star}$ & $18.4(16.9 \text { to } 19.7)^{\gamma}$ & 0.97 \\
\hline TNF- $\alpha$ (pg) & $17.5 \pm 0.33$ & $17.1 \pm 0.46$ & 0.003 & $0.79(0.22 \text { to } 1.36)^{\star \star \star}$ & 0.31 \\
\hline Adiponectin (pg) & $3.2(1.7)^{\star}$ & $6.7(2.1)^{\star}$ & $0.000^{\star \star}$ & $-2.98(-3.77 \text { to }-2.05)^{\gamma}$ & 0.63 \\
\hline Antioxidant (mM Trolox/L) & $3.6(1.3)^{\star}$ & $4.9(1)^{\star}$ & $0.000^{* *}$ & $-1.84(-2.25 \text { to }-1.44)^{r}$ & 0.72 \\
\hline BMI (kg/m2) & $29.5 \pm 3$ & $29.3 \pm 2.9$ & 0.020 & $0.07(-0.48 \text { to } 0.61)^{\star * \star}$ & 0.21 \\
\hline $\mathrm{PCR}(\mathrm{mg} / \mathrm{dL})$ & $0.2(0.2)^{*}$ & $0.1(0.5)^{\star}$ & $0.767^{\star \star}$ & $-0.01(-0.12 \text { to } 0.08)^{r}$ & 0.04 \\
\hline
\end{tabular}

Mean \pm SD, T-student for repeated samples *Median (Rq), **Wilcoxon test, $\mathrm{p}<0.05, \mathrm{IL}-1 \beta=$ Interleukin-1 $\beta$, IL-6= Interleukin-6, TNF- $\alpha=$ Tumor Necrosis Factor $\alpha$,

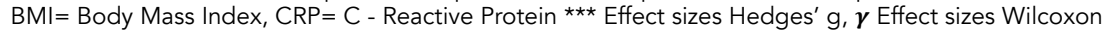


product in the serving previously mentioned does not promote excessive weight gain, and it is suitable for consumption in patients with obesity and diabetes. Besides, according to the microbiological analysis, the levels of molds and yeasts recount of the osmo-dehydrated Andean Berry were under the limits established by the Colombian normativity for dehydrated fruits (28), indicated that this product is safe for consumption and is potentially marketable.

Osmo-dehydrated Andean Berry presented a total phenolic content of $692.7 \pm 47.4 \mathrm{mg} \mathrm{GAE} / 100 \mathrm{~g}$, which is mainly constituted of chlorogenic acid, cyanidin-3-galactoside, and quercetin (29), this value was higher than that reported for fresh fruit $(609 \pm 31 \mathrm{mg} \mathrm{GAE} / 100 \mathrm{~g})$ (16). A similar result was observed by Dermesonlouoglou et al. 2018 after osmotic dehydration and air-drying treatment of the goji berry, whose total phenolic content increased $(1,505 \pm 245 \mathrm{mg}$ GAE/100 g osmo-dehydrated berry) compared to fresh berry $(1,212 \pm 68 \mathrm{mg}$ GAE/100 g fresh berry) (30). Our result suggests that osmotic dehydration could have concentrated the Andean Berry phenolic compounds in the final product by the diffusion of water from the fruit to the hypertonic solution.

Concerning the antioxidant capacity, the processed berries showed high antioxidant activity as indicated by the FRAP, DPPH, and ORAC values. The oxygen radical absorbance capacity was $11,490.8 \pm 631.6 \mu \mathrm{mol}$ TE/100 $\mathrm{g}$. This ORAC value was greater than that one reported for other fresh berries like cranberry $(1,850 \mu \mathrm{mol}$ TE/100 g), strawberry $(5,303 \mu \mathrm{mol} T E / 100 \mathrm{~g})(10)$ and bog blueberry (Vaccinium uliginosum, 4,568 umol TE/100 g) (31). The antioxidant activity of Andean Berry has been attributed to its phenolic compounds such as anthocyanins and phenolic acids (15). Health benefits derived from eating fruits rich in anthocyanins have been described by in vitro and animal model studies. These studies have reported the capacity of anthocyanins to i) scavenge or quench oxygen free radical; ii) protect DNA, proteins, and lipids from reactive oxygen species (ROS); iii) inhibit oxidative enzymes; iv) inhibit oncogene expression; and v) regulate essential cellular processes, including inflammation, proliferation, and angiogenesis $(32,33)$.

Our study performed a sensory analysis of the osmo-dehydrated Andean Berry, which classified this processed fruit as a high organoleptic quality product. Knowing that sight, smell, and taste of food are some of the most important features for food choice and intake control in people (34), designing a high palatable food was one of the most crucial processes to guarantee the adherence of the subjects to the study.

Our results showed that $35 \mathrm{~g}$ of osmo-dehydrated Andean Berry for 21 days of consumption significantly decreased the plasma levels of IL-6, $\mathrm{IL}-1 \beta, \mathrm{TNF}-\alpha$, and BMI of the group. Nevertheless, according to the Hedges' $g$ test, the effect size in reducing this last anthropometric indicator was 0.07 , classified as a small effect size, which also contains 0 in its confidence interval; thus, this effect size is not statistically significant. Similar findings were reported by Johnson et al. 2015 in an 8-week, randomized, double-blind, placebo-controlled clinical trial conducted in 48 postmenopausal women, where daily supplementation of $22 \mathrm{~g}$ freezedried blueberry (Vaccinium corymbosum) powder showed no significant changes in BMI (35). However, considering that the intervention period was only 21 days and that during this period, the decrease in $\mathrm{BMI}$ presented a statistically significant difference, it is possible to suggest that the consumption of the osmo-dehydrated berry for a more extended period could generate a greater decrease in the BMI and therefore a larger effect size.

IL-6 presented the greatest reduction and the largest effect size among all pro-inflammatory biomarkers analyzed here. Alternatively, adiponectin levels and antioxidant capacity in plasma significantly increased at the end of the study. Several studies have evidenced that high levels of pro-inflammatory cytokines and low adiponectin secretion in overweight and obese adults are associated with a higher risk of developing cancer (6). Thus, interventions to counteract the chronic inflammation generated by adipose tissue hypertrophy, such as that described in our study, are therapeutic strategies that could help reduce the risk of developing chronic inflammation-associated cancers. Based on the currently available literature, the effect of the osmo-dehydrated Andean Berry on inflammatory adipokines, evidenced in our study, could be attributed to anthocyanins and their metabolites produced after gastrointestinal digestion, such as gallic acid and chlorogenic acid, identified as bioactive compounds $(36,37)$. These compounds have shown the ability to inhibit the activation of the transcription factors NF-KB and activator protein 1 (AP-1) and suppress the expression of pro-inflammatory genes such as inducible nitric oxide synthase (iNOS), cyclooxygenase-2 (COX-2), IL-1 $\beta$, and IL-6 $(38,39)$. Also, Liu et al., 
in a 12-week double-blind study, reported that daily supplementation with $320 \mathrm{mg}$ of isolated anthocyanins significantly increased adiponectin level in the treated group (40).

Considering all the findings previously presented, our results suggest that short-term consumption of osmo-dehydrated Andean Berry (at least for 21 days) has a health benefit on inflammatory state control and improvement in the antioxidant capacity of overweight and obese subjects.

\section{CONCLUSIONS}

Our results indicate that regular consumption of osmo-dehydrated Andean Berry contributes to decreasing pro-inflammatory biomarkers, improves the plasma antioxidant status of overweight and obese adults, but does not have a significant effect on weight control in the short term. Further studies are needed to evaluate the effect of its consumption on in vivo oxidative stress biomarkers, anthropometric indicators for a longer period, and patients with chronic inflammation-associated cancers.

Study limitations: a placebo control group was not included. In vivo oxidative stress biomarkers were not evaluated.

\section{CONFLICT OF INTEREST}

The authors state that they have no conflict of interest.

\section{FUNDING}

This work was supported by the School of Nutrition of the University of Antioquia, through the Strategy for Projecting Research of the Unit 2016, modality Research Groups and Master's Projects.

\section{ACKNOWLEDGMENTS}

The authors thank the Colombian Plant Chemistry Research Group of the University of Antioquia, for allowing the testing of adipokine levels and antioxidant capacity in their laboratory facilities.

\section{AUTHOR CONTRIBUTIONS}

Emerson Gallego-Peláez and María Elena Maldonado-Celis: conception and writing of project, planning and execution of experiments, data analysis and interpretation, writing of the manuscript. David Torres, Ana Gómez and Gladys Posada: collection of clinical, dietary and anthropometric data, follow-up of the participating subjects.

\section{REFERENCES}

1. Organization WH. Obesity and overweight. Obesity and Overweight factsheet from the WHO. 2018. http://www.who.int/ mediacentre/factsheets/fs311/en/index.html

2. Stephen S Lim, Theo Vos, Abraham D Flaxman, Goodarz Danaei KS, Heather Adair-Rohani, Markus Amann, H Ross Anderson KGA, Martin Aryee, Charles Atkinson, Loraine J Bacchus, Adil N Bahalim K, Balakrishnan, John Balmes SB-C, Lim SS, Vos T, et al. A comparative risk assessment of burden of disease and injury attributable to 67 risk factors and risk factor clusters in 21 regions, 1990-2010: a systematic analysis for the Global Burden of Disease Study 2010. Lancet. 2012;380(9859):2224-60. DOI: https://doi. org/10.1016/s0140-6736(12)61766-8

3. Lafontan M. Adipose tissue and adipocyte dysregulation. Diabetes Metab. 2014;40(1):16-28. DOI: http://dx.doi.org/10.1016/j. diabet.2013.08.002

4. Acoltzin Vidal C, Rabling Arellanos E. Obesidad. 1st ed. Universidad de Colima; 2014. 33-36 p.

5. Elinav E, Nowarski R, Thaiss CA, Hu B, Jin C, Flavell RA. Inflammationinduced cancer: Crosstalk between tumours, immune cells and microorganisms. Nat Rev Cancer. 2013;13(11):759-71. DOI: https:// doi.org/10.1038/nrc3611

6. Deng T, Lyon CJ, Bergin S, Caligiuri MA, Hsueh WA. Obesity, Inflammation, and Cancer. Annu Rev Pathol Mech Dis 2016;11(1):421-49. DOI: https://doi.org/10.1146/annurevpathol-012615-044359

7. Khan S, Shukla S, Sinha S, Meeran SM. Role of adipokines and cytokines in obesity-associated breast cancer: Therapeutic targets. Cytokine Growth Factor Rev. 2013;24(6):503-13. DOI: http://dx.doi.org/10.1016/j.cytogfr.2013.10.001

8. Katira A, Tan PH. Evolving role of adiponectin in cancercontroversies and update. Cancer Biol Med. 2016;13(1):101-19. DOI: https://doi.org/10.28092/j.issn.2095-3941.2015.0092

9. Maldonado Celis ME, Urango Marchena LA, Arismendi Bustamante LJ. Propiedades quimiopreventivas del mango y la manzana en el cańcer de colon. Salud(i)Ciencia. 2014;20(6):614-8. Available from: https://www.siicsalud.com/dato/sic/206/128728.pdf

10. Afrin S, Giampieri F, Gasparrini M, Forbes-Hernandez TY, VarelaLópez A, Quiles JL, et al. Chemopreventive and therapeutic effects of edible berries: A focus on colon cancer prevention and treatment. Vol. 21, Molecules. 2016. 1-40 p. DOI: https://doi. org $/ 10.3390 /$ molecules21020169

11. Tsuda T, Ueno Y, Yoshikawa T, Kojo H, Osawa T. Microarray profiling of gene expression in human adipocytes in response to anthocyanins. Biochem Pharmacol. 2006;71(8):1184-97. DOI: https://doi.org/10.1016/j.bcp.2005.12.042

12. Tsuda T. Regulation of Adipocyte Function by Anthocyanins; J Agric Food Chem. 2008;56:642-6. DOI: https://doi.org/10.1021/ jf073113b

13. Karlsen A, Paur I, Bøhn SK, Sakhi AK, Borge GI, Serafini M, et al. Bilberry juice modulates plasma concentration of NF-KB related inflammatory markers in subjects at increased risk of CVD. Eur $J$ Nutr. 2010;49(6):345-55. DOI: https://doi.org/10.1007/s00394010-0092-0

14. Kolehmainen $M$, Mykkänen $O$, Kirjavainen $P$ V., Leppänen $T$, Moilanen E, Adriaens $M$, et al. Bilberries reduce low-grade 
inflammation in individuals with features of metabolic syndrome. Mol Nutr Food Res. 2012;56(10):1501-10. DOI: https://doi. org/10.1002/mnfr.201200195.

15. Maldonado Celis ME, Franco Tobón YN, Agudelo C, Arango-Varela SS, Rojano B. Andean Berry (Vaccinium meridionale Swartz). In: Fruit and Vegetable Phytochemicals: Chemistry and Human Health, Volume 2. 2nd ed. 2017. p. 869-82.

16. Gaviria CA, Ochoa Cl, Sánchez NY, Medina Cl, Lobo M, Galeano $\mathrm{PL}$, et al. Propiedades antioxidantes de los frutos de agraz o mortiño (Vaccinium meridionale Swartz). In: Perspectivas del cultivo de agraz o mortiño. 1st ed. 2009. p. 93-109.

17. Maldonado-Celis ME, Arango-Varela SS, Rojano BA. Free radical scavenging capacity and cytotoxic and antiproliferative effects of Vaccinium meridionale Sw. agains colon cancer cell lines. Rev Cuba Plantas Med. 2014;19(2):172-84. Available from: http://scielo.sld.cu/scielo.php?script=sci_arttext\&pid=S1028 47962014000200006\&lng=es.

18. Zapata Vahos IC, Ochoa S, Maldonado-Celis ME, Zapata Zapata AD, Rojano B. Cytotoxic effect and antioxidant activity of Andean berry (Vaccinium meridionale Sw) wine. J Med Plants Res. 2016;10(27):402-8. DOI: 1 https://doi.org/0.5897/JMPR2016.6100

19. Zapata Vahos IC, Villacorta V, Maldonado-Celis ME, Castro Resptrepo D, Rojano B. Antioxidant and cytotoxic activity of black and green tea from Vaccinium meridionale Swartz leaves. J Med Plants Res. 2015;9(13):445-53. DOI: https://doi.org/10.5897/ JMPR2014.5744

20. Ahmed I, Qazi IM, Jamal S. Developments in osmotic dehydration technique for the preservation of fruits and vegetables. Innov Food Sci Emerg Technol. 2016;34:29-43. DOI: http://dx.doi. org/10.1016/j.ifset.2016.01.003

21. Osorio C, Franco MS, Castaño MP, González-Miret ML, Heredia FJ, Morales AL. Colour and flavour changes during osmotic dehydration of fruits. Innov Food Sci Emerg Technol. 2007;8(3):353-9. DOI: https://doi.org/10.1016/j.ifset.2007.03.009

22. García Carvajal E, Vásquez MV, Peláez C. Determinación de las características fisicoquímicas y las propiedades bioactivas del fruto mortiño (Vaccinium Merdionale Swartz) y su relación con los estadios de maduración. [Grade Work]. [Medellín, Colombia]: Universidad de Antioquia; 2015.

23. Brand-Williams, Cuvelier ME, Berset C. Use of a Free Radical Method to Evaluate Antioxidant Activity. Food Sci Technol. 1995;28:25-30. DOI: https://doi.org/10.1016/S0023-6438(95)80008-5

24. Benzie IFF, Strain JJ. The ferric reducing ability of plasma (FRAP) as a measure of "antioxidant power": The FRAP assay. Anal Biochem. 1996;239(1):70-6. DOI: https://doi.org/10.1006/abio.1996.0292

25. Zapata K, Cortes FB, Rojano BA. Polifenoles y Actividad Antioxidante del Fruto de Guayaba Agria (Psidium araca). Inf Tecnol. 2013;24(5):103-12. DOI: https://doi.org/10.4067/S071807642013000500012

26. Singleton VL, Rossi JA. Colorimetry of total phenolics with phosphomolybdic-phosphotungstic acid reagents. Am J Enol Vitic. 1965;16:144-58. Available from: https://www.ajevonline.org/ content/16/3/144

27. Ministerio de salud y protección social. Guía de práctica clínica para el diagnóstico, seguimiento de la DM tipo 2 en la población mayor de 18 años [Internet]. Vol. IMSS-191-1, Gpc. 2016. 129 p. Available from: http://gpc.minsalud.gov.co/gpc_sites/Repositorio/ Conv_637/GPC_diabetes/DIABETES_TIPO_2_COMPLETA.pdf
28. Ministerio de Salud y Protección Social. Resolución 3929 [Internet]. 2013 p. 21-2. Available from: https://www.invima.gov.co/ documents/20143/441425/Resolucion-3929-2013.pdf/28252dd641eb-a575-8ec4-c876e6326a5e

29. Garzón GA, Narváez CE, Riedl KM, Schwartz SJ. Chemical composition, anthocyanins, non-anthocyanin phenolics and antioxidant activity of wild bilberry (Vaccinium meridionale Swartz) from Colombia. Food Chem. 2010;122(4):980-6. DOI: https://doi. org/10.1016/j.foodchem.2010.03.017

30. Dermesonlouoglou E, Chalkia A, Taoukis P. Application of osmotic dehydration to improve the quality of dried goji berry. J Food Eng. 2018;232:36-43. DOI: https://doi.org/10.1016/j. jfoodeng.2018.03.012

31. Kraujalyte V, Venskutonis PR, Pukalskas A, Česoniene L, Daubaras R. Antioxidant properties, phenolic composition and potentiometric sensor array evaluation of commercial and new blueberry (Vaccinium corymbosum) and bog blueberry (Vaccinium uliginosum) genotypes. Food Chem. 2015;188(August):583-90. DOI: https://doi.org/10.1016/j.foodchem.2015.05.031

32. Kristo A, Klimis-Zacas D, Sikalidis A. Protective Role of Dietary Berries in Cancer. Antioxidants. 2016;5(4):37. DOI: https://doi. org/10.3390/antiox5040037

33. Lee YM, Yoon Y, Yoon H, Park HM, Song S, Yeum KJ. Dietary anthocyanins against obesity and inflammation. Nutrients. 2017;9(10):1-15. DOI: https://doi.org/10.3390/nu9101089

34. Mccrickerd K, Forde CG. Sensory influences on food intake control: Moving beyond palatability. Obes Rev. 2016;17(1):18-29. DOI: https://doi.org/10.1111/obr.12340

35. Johnson SA, Figueroa A, Navaei N, Wong A, Kalfon R, Ormsbee LT, et al. Daily blueberry consumption improves blood pressure and arterial stiffness in postmenopausal women with pre- and stage 1-hypertension: A randomized, double-blind, placebo-controlled clinical trial. J Acad Nutr Diet. 2015;115(3):369-77. DOI: http:// dx.doi.org/10.1016/j.jand.2014.11.001

36. Brown EM, McDougall GJ, Stewart D, Pereira-Caro G, GonzálezBarrio R, Allsopp P, et al. Persistence of Anticancer Activity in Berry Extracts after Simulated Gastrointestinal Digestion and Colonic Fermentation. PLoS One. 2012;7(11):3-12. DOI: https:// doi.org/10.1371/journal.pone.0049740

37. Luzardo-Ocampo I, Campos-Vega R, Gaytán-Martínez M, Preciado-Ortiz R, Mendoza S, Loarca-Piña G. Bioaccessibility and antioxidant activity of free phenolic compounds and oligosaccharides from corn (Zea mays L.) and common bean (Phaseolus vulgaris L.) chips during in vitro gastrointestinal digestion and simulated colonic fermentation. Food Res Int. 2017;100(March):304-11. DOI: https://doi.org/10.1016/j. foodres.2017.07.018

38. Li L, Wang L, Wu Z, Yao L, Wu Y, Huang L, et al. Anthocyanin-rich fractions from red raspberries attenuate inflammation in both RAW264.7 macrophages and a mouse model of colitis. Sci Rep. 2014:4:1-11. DOI: https://doi.org/10.1038/srep06234

39. Joseph S V., Edirisinghe I, Burton-Freeman BM. Berries: Anti-inflammatory effects in humans. J Agric Food Chem. 2014;62(18):3886-903. DOI: https://doi.org/10.1021/jf4044056

40. Liu Y, Li D, Zhang Y, Sun R, Xia M. Anthocyanin increases adiponectin secretion and protects against diabetes-related endothelial dysfunction. AJP Endocrinol Metab. 2014;306(8): E975-88. DOI: https://doi.org/10.1152/ajpendo.00699.2013 